\title{
INTEGRATED IPA MODULE BASED ON GUIDED INQUIRY ON MATERIALS FOOD ADDITIVES TO INCREASE LEARNING OUTCOMES
}

\author{
Tiurlina Siregar ${ }^{1)}$, Siti Patimah ${ }^{2)}$ \\ ${ }^{1)}$ Program Studi Magister Pendidikan IPA, UNCEN; tiurlina.siregar66@gmail.com \\ ${ }^{2)}$ SMP Negeri 1 Sentani ; sitip736@gmail.com
}

\begin{abstract}
This study aims to determine the feasibility of developing an integrated science module and student learning outcomes using an integrated science module based on guided inquiry on food additives. Research Methods Research and Development. The research sample was carried out in class VIII B of SMP Negeri 1 Sentani with a total of 30 students. The results showed that the feasibility of an integrated science module based on guided inquiry on food additives in the category of very suitable for use as teaching materials and improving student learning outcomes with the $n$-Gain test obtained an average of 0.74 in the high category.
\end{abstract}

Keywords: Science Module; Guided Inquiry; Food additives.

\section{ABSTRAK}

Penelitian ini bertujuan untuk mengetahui kelayakan pengembangan modul IPA terpadu dan hasil belajar peserta didik dengan menggunakan modul IPA terpadu berbasis inkuiri terbimbing pada materi zat aditif makanan. Metode Penelitian Research and Development. Sampel penelitian dilaksanakan di kelas VIII B SMP Negeri 1 Sentani dengan jumlah 30 peserta didik. Hasil penelitian menunjukkan bahwa kelayakan modul IPA terpadu berbasis inkuiri terbimbing pada materi zat aditif makanan kategori sangat layak digunakan sebagai bahan ajar dan peningkatan hasil belajar peserta didik dengan uji $n$-Gain diperoleh rata-rata 0,74 dengan kategori tinggi.

Kata Kunci : Modul IPA; Inkuiri Terbimbing; Zat aditif makanan.

\section{PENDAHULUAN}

Pendidikan merupakan suatu proses kompleks yang di dalamnya terdapat proses belajar-mengajar yang di alami peserta didik sebagai anak didik. Menurut Gulo dalam Huda (2018) strategi pembelajaran inkuiri berarti suatu rangkaian kegatan belajar yang melibatkan secara maksimal seluruh kemampuan peserta didik untuk mencari dan menyelidiki secara sistematis, kritis, logis, sehingga peserta didik dengan penuh percaya diridapat merumuskan sendiri penemuan-penemuannya. Inkuiri merupakan bagian inti dari kegiatan pembelajaran berbasis kontekstual, sehingga pengetahuan dan keterampilan yang diperoleh peserta didik diharapkan bukan hasil mengingat seperangkat fakta melainkan hasil dari menemukan sendiri (Huda, 2018). Pembelajaran inquiry merupakan pembelajaran yang menekankan kepada pengembangan aspek kognitif, afektif, dan psikomotor secara 
seimbang. Pembelajaran dianggap jauh lebih bermakna bila dapat memberikan ruang kepada peserta didik untuk belajar mandiri. Strategi yang dianggap sesuai dengan perkembangan psikologi belajar modern adalah proses perubahan tingkah laku berkat adanya pengalaman peserta didik melalui aplikasi konsep dalam kehidupan sehari-hari. (Huda, 2018).

Konsep dalam kehidupan sehari-hari zat aditif makanan tidak asing lagi bagi peserta didik, selain itu materi zat aditif bahan makanan merupakan salah satu materi IPA kimia untuk SMP kelas VIII pada kurikulum 2013. Materi zat aditif memuat sub materi pewarna, pemanis, pengawet, dan penyedap. Zat aditif berupa pewarna, pemanis, pengawet, dan penyedap dapat digolongkan secara alami dan sintetis (buatan). Bahan aditif alami, sebagian besarnya adalah yang berasal dari tumbuhan, hal ini sejalan dengan beberapa penelitian yang telah dilakukan sebelumnya tentang pemanfaatan tumbuhan sebagai zat aditif (Andriani, Masriani, \& Muharini, 2019). Materi zat aditif di SMP Negeri 1 Sentani hanya diajarkan melalui pembelajaran teori di kelas. Hal tersebut tidak sesuai dengan kurikulum 2013 karena keterampilan sains peserta didik belum tampak yang mengakibatkan peluang peserta didik untuk belajar mandiri dalam meningkatkan keterampilan sains dan hasil belajar belum maksimal, sehingga dalam pelaksanaannya harus dibantu dengan bahan ajar yang menunjang agar peserta didik dapat memahami materi zat aditif makanan. Salah satu bahan ajar yang dapat digunakan adalah modul IPA Terpadu.

Modul dapat digunakan sebagai bahan ajar bagi peserta didik yang dapat dipelajari dimana saja dan kapan sajatanpa ada harus ada alat pendukung. Modul juga berperan dalam melatih peserta didik untuk belajar aktif serta dapat pula menunjang keefektifan pencapaian tujuan pembelajaran. Pembelajaran inkuiri terbimbing merupakan suatu rangkaian kegiatan belajar yang melibatkan secara maksimal seluruh kemampuan peserta didik untuk mencari dan menyelidiki secara sistematis, kritis, logis, analitis, sehingga peserta didik dapat merumuskan sendiri penemuan-penemuannya dengan penuh percaya diri.

Penggunaan modul diharapkan dapat mengatasi kesulitan yang dihadapi guru dalam mencapai tujuan pembelajaran materi IPA, kesulitan mencapai tujuan pembelajaran disebabkan oleh : (1) Input peserta didik rendah, (2) Guru kurang aktif mengembangkan bahan ajar yang disesuiakan dengan metode pembelajaran serta karakteristik pesrta didik, rendahnya motivasi belajar peserta didik, (4) pembelajaran masih menggunakan pola terpusat pada guru dan berorentasi pada pencapaian nilai ujian yang baik, namun bukan pembelajaran yang memberikan 
pengalaman belajar kepada peserta didik, sehingga aktivitas pembelajaran cenderung bersifat hafalan yang menyebabkan kemampuan peserta didik sangat lemah, dan cenderung menghafal rumus dari pada memahami konsep, sehingga peserta didik menjadi pasif dalam kegiatan pembelajaran.

Berdasarkan penelitian sebelumnya yang dilakukan oleh Insar Damopolii, Aksamina M. Yohanita, N. Nurhidaya, M. Murtijani, (2018), Meningkatkan keterampilan proses sains dan hasil belajar peserta didik melalui pembelajaran berbasis inkuiri. Besar peningkatan hasil belajar adalah 5,27\%. Kesimpulan dari penelitian ini adalah hasil belajar peserta didik kelas XI IPA SMA Yapis Manokwari dapat ditingkatkan melalui pembelajaran berbasis inkuiri. Penelitian di atas mendasari penelitian dan pengembangan modul IPA terpadu berbasis inkuiri terbimbing pada materi zat aditif makanan untuk meningkatkan hasil belajar peserta didik SMP Negeri 1 Sentani.

Berdasarkan pengalaman dan observasi penulis, materi IPA terpadu zat aditif makanan yang dianggap mudah dipahami oleh peserta didik dan konsep berkaitan dalam kehidupan sehari-hari tidak perlu lagi diajarkan sesuai dengan prosedur yang ada atau hanya biasa diberikan penugasan saja karena dianggap mudah. Namun kenyataannya banyak peserta didik belum memahaminya, tanpa melalui praktikum atau demontrasi di depan kelas tentang materi tersebut. Disini peserta didik hanya menghafal tanpa mengetahui konsep dasarnya, sehingga peserta didik mengalami kesulitan menghadapi soal yang diberikan oleh guru. Motivasi belajar peserta didik yang rendah lebih memperburuk hasil belajar peserta didik. Materi zat aditif makanan memiliki Kriteria Ketuntasan Minimal (KKM) 70, namun kenyataannya nilai peserta didik untuk materi tersebut lebih dari 50\% masih berada di bawah KKM, jika dilihat dari hasil ulangan harian peserta didik kelas VIII.

\section{METODE PENELITIAN}

Metode penelitian yang digunakan dalam penelitian ini adalah penelitian dan pengembangan (Research and Development), untuk menghasilkan produk. Produk yang dikembangkan dalam penelitian ini adalah modul IPA terpadu dengan materi zat aditif pada makanan berbasis inkuiri terbimbing. Tahap perkembangan modul adalah pendefinisian (Define), Perancangan (Design), Pengembangan (Develop), dan penyebaran (Desseminate), disebut tahap-tahap pengembangan model siklus 4D oleh Sugiyono (Puji Rahayu, 2019).

Populasi dalam penelitian ini adalah peserta didik kelas VIII SMP Negeri 1 Sentani kabupaten Jayapura. Jumlah populasi adalah 283 peserta didik. Dalam uji coba skala terbatas, uji coba skala luas 
dan kelas penerapan modul IPA terpadu materi zat aditif makanan dengan model inkuiri terbimbing. Sampel adalah peserta didik kelas VIII B yang berjumlah 30 peserta didik.

Instrumen penelitian yang digunakan untuk mengumpulkan data hasi penelitian adalah :

\section{Observasi}

Dilakukan observasi partisipasif, peneliti terlibat langsung dalam proses pembelajaran dan kegiatan keterampilan proses sains terhadap sintaks inquiry learning dalam keaktifan peserta didik.

2. Kuisioner

Kuisioner sebagai penilaian kelayakan produk hasil pengembangan modul IPA terpadu berbasis inquiry learning yang dinilai oleh validator yaitu validasi ahli materi yang terdiri dari aspek kelayakan isi, aspek kebahasaan dan asek penyajian dan penilaian validasi ahli media yaitu aspek kegrafikan. Kuisioner juga diberikan kepada peserta didik dan guru IPA Terpadu SMP Negeri 1 Sentani, untuk mengetahui tanggapan terhadap modul IPA Terpadu yang dikembangkan. Wawancara

Wawancara dilakukan untuk memperoleh data tanggapan peserta didik dan tanggapan guru IPA Terpadu SMP Negeri 1 Sentani terhadap modul IPA Terpadu yang dikembangkan dalam pembelajaran.

Analisis instrumen yang dilakukan yaitu analisis deskriptif persentase, untuk menganalisa penilaian kelayakan modul oleh validator ahli materi dan validator ahli media, tanggapan peserta didik serta tanggapan guru IPA Terpadu SMP Negeri 1 Sentani pada proses pembelajaran.

\section{HASIL DAN PEMBAHASAN}

Kelayakan Pengembangan Modul IPA Terpadu Berbasis Inkuiri Terbimbing pada Materi Zat Aditif Makanan

Analisis penilaian modul dari aspek kelayakan isi, aspek kelayakan penyajian, dan aspek kebahasaan dapat dilihat pada Tabel 1, 2, dan 3, sebagai berikut :

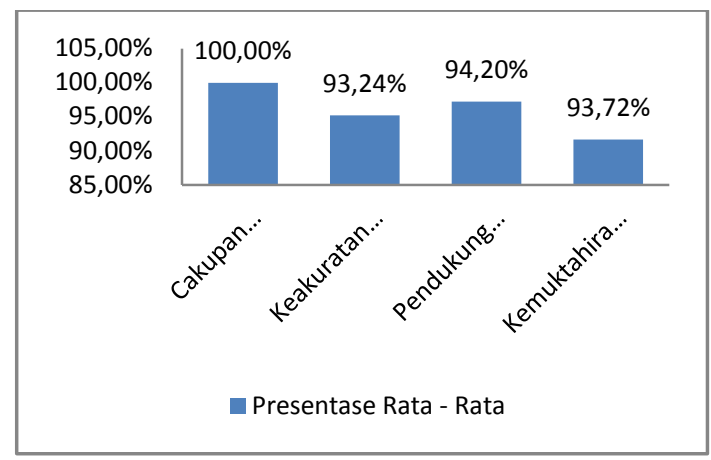

Tabel 1. Grafik Kelayakan Materi Modul

Berdasarkan Tabel 1 menunjukkan bahwa rata-rata persentase hasil penilaian aspek kelayakan materi modul dari ketiga validator berkisar antara 93,72\% sampai 100\%. Aspek kemutakhiran materi mendapatkan nilai rata-rata $93,72 \%$, aspek pendukung materi mendapatkan nilai ratarata $97,22 \%$, aspek keakuratan materi mendapatkan nilai rata-rata $95,24 \%$, dan aspek cakupan materi serta pendukung materi mendapatkan nilai rata-rata $100,00 \%$. Berdasarkan ketercapaian nilai rata-rata keempat aspek dalam kelayakan isi modul $(96,03 \%)$ dapat dinyatakan 
bahwa modul sangat layak digunakan tanpa revisi.

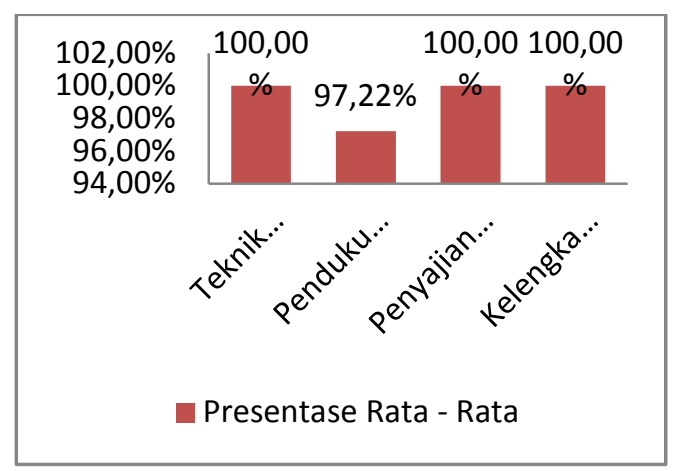

Tabel 2 Grafik Kelayakan Penyajian Modul

Berdasarkan Tabel 2. diketahui bahwa persentase hasil validasi aspek kelayakan penyajian modul dari ketiga validator berkisar antara 97,22\% sampai 100,00\%. Aspek teknik penyajian, penyajian pembelajaran, dan kelengkapan penyajian mendapatkan nilai persentase $100,00 \%$, sedangkan aspek pendukung penyajian memperoleh nilai $97,22 \%$.

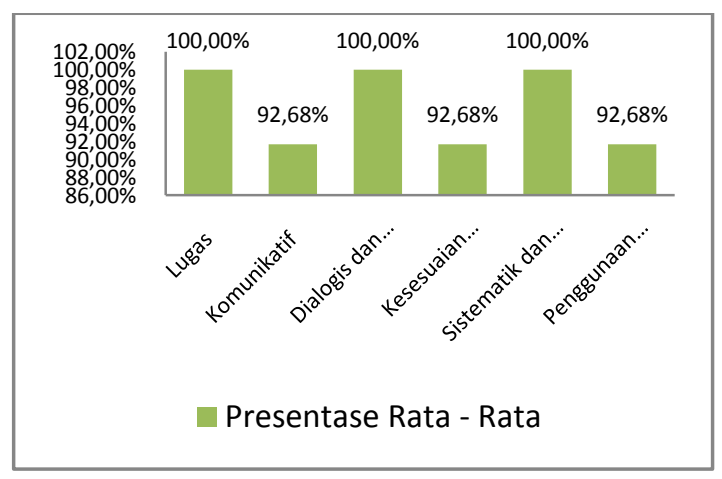

Tabel 3. Grafik Kebahasaan Modul

Rata-rata persentase (Tabel 3) hasil penilaian aspek kebahasaan modul dari ketiga validator berkisar antara 92,68\% dan 100,00\%. Aspek lugas, dialogis, dan sistematik mendapatkan nilai validasi $100,00 \%$, sedangkan aspek komunikatif, kesesuaian, dan istilah/simbol mendapatkan nilai validasi $92,68 \%$. Hal tersebut menunjukkan penggunaan bahasa dalam modul termasuk kategori sangat layak dengan nilai rata-rata 95,83\%. Hasil analisis dari ketiga aspek yaitu aspek isi, penyajian dan kebahasaan maka modul IPA terpadu berbasis inkuiri terbimbing pada materi zat aditif makanan sangat layak digunakan. Hal ini dikuatkan dengan pendapat dari (Wiwin \& Sudarmia, 2015) bahwa penggunaan modul dalam proses belajar mengajar bertujuan agar tujuan pembelajaran dapat dicapai secara efektif dan efisien.

\section{Peningkatan Hasil Belajar Peserta Didik dengan Menggunakan Modul IPA Terpadu Berbasis Inkuiri Terbimbing pada Materi Zat Aditif pada Makanan}

Tingkat pemahaman peserta didik terhadap materi zat aditif pada makanan dilakukan menggunakan hasil belajar kognitif berupa nilai pretest dan posttest. Pretest dilakukan sebelum pembelajaran dan posttest dilakukan setelah pembelajaran menggunakan modul IPA terpadu. Pembelajaran berbasis inquiry merupakan metode pembelajaran yang memberi ruang sebebas-bebasnya bagi peserta didik untuk menemukan cara belajarnya masing- masing. Peserta didik tidak lagi dipaksa untuk belajar dengan gaya atau cara tertentu, namun dikembangkan untuk menjadi pembelajar yang kreatif dan produktif. . Intisari dan potensi-potensi pengembangan atas materi pelajaran tertentumerupakan nilai 
positifnya bagi peserta didik untuk mengetahui dan memahami materi pembelajaran. Titik tekan utama pada pembelajaran berbasis inquiry tidak lagi berpusat pada guru (teacher-centered instruction), tetapi juga pengembangan nalar kritis pada peserta didik (studentcentered approach). Kata kunci inquiry menurut Nurhadi, dkk dalam Tiurlina siregar (2011) adalah peserta didik dapat menemukan sendiri dalam pengembangan pengetahuan dan keterampilan pada proses pembelajaran. Berdasarkan pendapat tersebut dan hasil uji kelayakan dari validator modul IPA terpadu dikembangkan untuk meningkatkan hasil belajar peserta didik.

Hasil belajar peserta didik sebagai penentu dalam mencapai KKM (kriteria ketuntasan minimal) individual yang ditetapkan yaitu 70. Hasil belajar peserta didik dapat dilihat pada Tabel 4 dan 5 sebagai berikut :

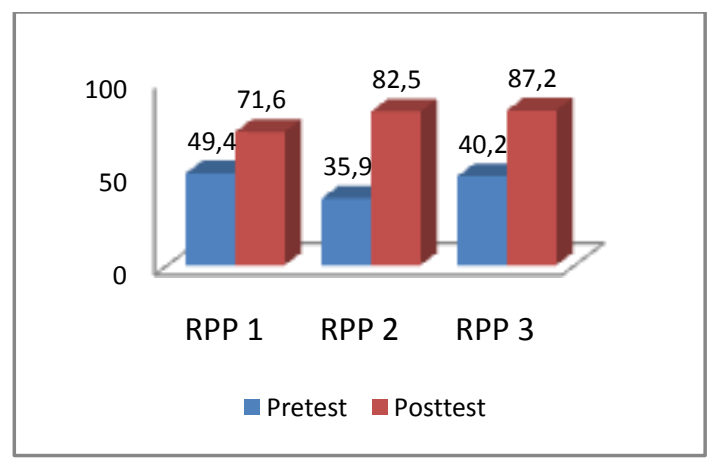

Tabel 4. Grafik Hasil Belajar Peserta Didik

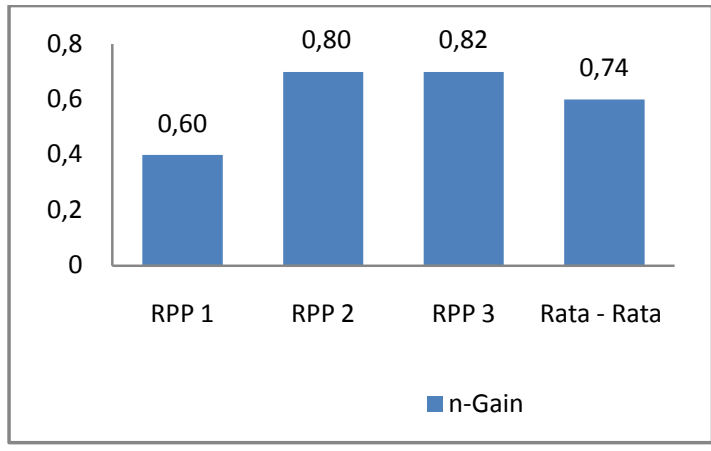

Tabel 5. Grafik Hasil Uji n-Gain Rata-Rata

Berdasarkan Tabel 4 dan 5 menunjukkan bahwa :

1. Hasil belajar n-Gain rata-rata RPP 1 Nilai rata-rata pretest pada RPP 1 sebesar 49,4 sedang nilai rata-rata posttest sebesar 71,6 , berarti ada peningkatan sebesar 22,2 dengan uji n-Gain rata-rata diperoleh hasil sebesar 0,60 maka penguasaan konsep peserta didik termasuk dalam kategori sedang. Hal ini disebabkan peserta didik kesulitan dalam memahami materi zat aditif pada makanan, tidak serius dalam belajar, tidak membaca modul dengan seksama, dan wawasan yang rendah. Alasan lain yaitu belum terbiasa dengan langkah-langkah kegiatan inkuiri terbimbing dan masih memerlukan waktu untuk pembiasaan dalam penggunaan modul.

2. Hasil belajar dan nilai n-Gain RPP 2

Nilai rata-rata pretest pada RPP 2 sebesar 35,9 sedang nilai rata-rata posttest sebesar 82,5 berarti ada peningkatan sebesar 46,6 dengan uji n-Gain rata-rata diperoleh hasil sebesar 0,80 maka penguasaan konsep peserta didik termasuk dalam kategori tinggi. Hal ini disebabkan 
peserta didik yang sudah mulai terbiasa dengan inkuiri terbimbing, modul IPA memberikan pengaruh positif dengan meningkatnya nilai posttest, terbukti dengan bertambahnya nilai $\mathrm{n}$-Gain ratarata. Hasil penelitian dari Yohanita, A.M., dkk (2018) mendukung bahwa penggunaan metode inkuiri dapat meningkatkan hasil belajar peserta didik kelas XI IPA SMA Yapis Manokwari.

\section{Hasil belajar dan nilai n-Gain RPP 3}

Nilai rata-rata pretest pada RPP 3 sebesar 40,2 sedang nilai rata-rata posttest sebesar 87,2 berarti ada peningkatan sebesar 47 dengan uji n-Gain rata-rata diperoleh hasil sebesar 0,82 maka penguasaan konsep peserta didik termasuk dalam kategori tinggi. Rata-rata secara keseluruhan n-Gain adalah 0,74 dengan kategori tinggi. Hal ini mengindikasikan penggunaan modul IPA terpadu berbasis inkuiri terbimbing dalam pembelajaran dapat meningkatkan pemahaman terhadap materi pelajaran dan meningkatkan hasil belajar. Tingginya nilai posttest disebabakan karena pada pertemuan ke tiga ini materinya menarik dan disukai oleh peserta didik.

Setelah mengamati hasil belajar selama 3kali pertemuan, diperoleh nilai rata-rata $\mathrm{n}$-Gain 0,74 kategori tinggi. Menurut Adriyani putri, dkk (2018). Materi zat aditif bahan makanan merupakan salah satu materi IPA terpadu untuk SMP kelas VIII pada kurikulum
2013. Materi zat aditif terdiri atas pengawet, pewarna, pemanis, dan penyedap.. dimana zat aditif digolongkan secarasintetis atau buatan dan alami.Semua bahan yang ditambahkan ke dalam makanan selama proses pengolahan, penyimpanan, atau pengepakan makanan di sebut zat aditif makanan. Hal ini membuktikan bahwa penggunaan modul IPA terpadu dapat meningkatkan hasil belajar, dengan melihat kecenderungannya semakin meningkatnya $\mathrm{n}$-Gain rata-rata terhadap penggunaan modul IPA terpadu pada materi berikutnya. Penilaian terhadap penguasaan konsep peserta didik dilakukan dengan menghitung n-Gain rata-rata terhadap hasil pretest dan posttest yang dikerjakan peserta didik. Rata - rata nilai pretest sebesar 44,37 dan rata - rata nilai posttest 79,07, menghasilkan n-Gain ratarata dari RPP 1 sampai RPP 3 termasuk dalam kategori sedang $(0,6)$. Berdasarkan hasil perhitungan $\mathrm{n}$-Gain dapat diketahui bahwa modul IPA terpadu yang dikembangkan telah berpengaruh baik terhadap penguasaan konsep peserta didik dalam materi zat aditif pada makanan.

Hal ini terjadi karena peserta didik pada RPP1 peserta didik belum terbiasa menggunakan modul dalam proses pembelajaran dan pada RPP2 serta RPP3 peserta didik sudah terbiasa menggunakan modul IPA terpadu berbasis inkuiri terbimbing, sehingga materi yang dijelaskan lebih mudah dipahami. Hal 
senada dinyatakan oleh Siti Patimah,dkk (2021) bahwa modul IPA Terpadu berbasis inquiry learning dapat digunakan untuk meningkatkan keterampilan proses sains (KPS) peserta didik dan hal yang sama dikemukakan oleh Tiurlina Siregar, Desry Natalia (2019) bahwa Penggunaan Modul Berbasis Inkuiri terbimbing dapat meningkatkan hasil belajar kimia pada materi larutan elektrolit dan non-elektrolit dengan $\mathrm{n}$-Gain rata-rata sebesar 0,72 kategori tinggi.

\section{SIMPULAN}

Modul IPA terpadu berbasis inkuiri terbimbng pada materi zat aditif makanan dapat meningkatkan hasil belajar peserta didik kelas VIII SMP Negeri 1 Sentani, nGain rata-rata sebesar 0,74 kategori tinggi.

\section{SARAN}

Modul IPA terpadu berbasis inkuiri terbimbing pada materi zat aditif makanan dapat digunakan untuk meningkatkan hasil belajar peserta didik.

\section{UCAPAN TERIMA KASIH}

Kepala sekolah SMP Negeri 1

Sentani dan program studi Magister Pendidikan IPA FKIP Universitas Cenderawasih yang telah bekerjasama dalam memberi dukungan pada penelitian ini.

\section{DAFTAR PUSTAKA}

Andriani, P. M. (2019). Pemanfaatan Tumbuhan Sebagai Zat Aditif Makanan Oleh Masyarakat Desa Rasau Jaya Umum Kabupaten
Kubu Raya. Jurnal Pendidikan Matematika dan IPA, 74-87;

Depdiknas. (2013). Undang-Undang RI Nomor 20 Tahun 2003, Tentang pendidikan Nasional. Jakarta: Biro Hukum Sekjen Depdiknas cet. 1.;

Huda, F. A. (2018, Maret 8). Pengertian dan Langkah-Langkah Model Pembelajaran Inquiry (Inquiry Learning). Retrieved Februari 2020, 14, from Fatkhan.Web.ID: http://fatkhan.web.id/pengertiandan-langkah langkah-modelpembelajaran-inkuiri-inquirylearning;

Insar Damopolii, A. M. (2018). Meningkatkan Keterampilan Proses Sains Dan Hasil Belajar Siswa Melalui Pembelajaran Berbasis Inkuiri. Jurnal Bioedukatika, Vol. 6. No. 1;

Kemendikbud. (2013). Sistem Pendidikan Nasional. Retrieved from http://lppks.kemdikbud.go.id/uploa ds/pengumuman/uu_no_20_tahun_ 2003.pf;

Puji Adriyani, M. R. (n.d.). Pengembangan Modul Zat Aditif Makanan Berbasis Kearifan Lokal Masyarakat Desa Rasau Jaya Umum. Jurnal Pendidikan Kimia Universitas Tanjung Pura;

Rahayu, P. (2019). Pengembangan Modul IPA berbasis Discovery Learning dalam Meningkatkan Keaktifan, Keterampilan Proses Dan Hasil Belajar Peserta Didik Pada Materi Getaran, Gelombang dan Bunyi Kelas VIII SMP YPK 2 Manokwari. Jurnal Ilmu Pendidikan Indonesia, Vol 8, No 2, Hal 95-102;

Siti Patimah, dkk, 2021, Modul Ipa Terpadu Berbasis Inquiry Learning 
Pada Materi Zat Aditif Makanan Untuk Meningkatkan Keterampilan Proses Sains, Jurnal Ilmu Pendidikan Indonesia, Vol 9, No 2, hal 61-67;

Siregar, T, (2011). Upaya Meningkatkan Hasil Belajar Kimia Melalui Model Pembelajaran dengan Pendekatan Inquiry Based Learning (IBL) . Jurnal Prosiding Seminar Nasional;

Siregar, T. (2011). Pendekatan inquiry Based Learning (IBL) mengubah paradigma pembelajaran menjadi inovatif. Jayapura: Logoz Publishing;

Siregar, T, dan Desry Natalia (2019). Modul pembelajaran inkuiri terbimbing pada materi larutan elektrolit dan non elektrolit. Jurnal Ilmu Pendidikan Indonesia, Vol 1, No 1, Hal 8-16;
Wiwin, R. E. (2015). Pengembangan Modul IPA Terpadu Berbasis Etnosains Tema Energi Dalam Kehidupan Untuk Menanamkan Jiwa Konvervasi Siswa. Unnesscience Education Jurnal, 920-926;

Yohanita, A. M. (2018). Meningkatkan Keterampilan Proses Sains Dan Hasil Belajar Peserta Didik Melalui Pembelajaran Berbasis Inkuiri. Jurnal Bioedukatika, 22-30. 